NASA/TM-2000-209891, Vol. 214

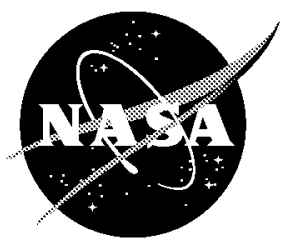

Technical Report Series on the Boreal Ecosystem-Atmosphere Study (BOREAS)

Forrest G. Hall and David E. Knapp, Editors

\title{
Volume 214 \\ BOREAS TF-11 SSA-Fen 1995 \\ Leaf Area Index Data
}

Timothy J. Arkebauer

University of Nebraska-Lincoln

National Aeronautics and

Space Administration

Goddard Space Flight Center

Greenbelt, Maryland 20771 
The NASA STI Program Office ... in Profile

Since its founding, NASA has been dedicated to the advancement of aeronautics and space science. The NASA Scientific and Technical Information (STI) Program Office plays a key part in helping NASA maintain this important role.

The NASA STI Program Office is operated by Langley Research Center, the lead center for NASA's scientific and technical information. The NASA STI Program Office provides access to the NASA STI Database, the largest collection of aeronautical and space science STI in the world. The Program Office is also NASA's institutional mechanism for disseminating the results of its research and development activities. These results are published by NASA in the NASA STI Report Series, which includes the following report types:

- TECHNICAL PUBLICATION. Reports of completed research or a major significant phase of research that present the results of NASA programs and include extensive data or theoretical analysis. Includes compilations of significant scientific and technical data and information deemed to be of continuing reference value. NASA's counterpart of peer-reviewed formal professional papers but has less stringent limitations on manuscript length and extent of graphic presentations.

- TECHNICAL MEMORANDUM. Scientific and technical findings that are preliminary or of specialized interest, e.g., quick release reports, working papers, and bibliographies that contain minimal annotation. Does not contain extensive analysis.

- CONTRACTOR REPORT. Scientific and technical findings by NASA-sponsored contractors and grantees.
- CONFERENCE PUBLICATION. Collected papers from scientific and technical conferences, symposia, seminars, or other meetings sponsored or cosponsored by NASA.

- SPECIAL PUBLICATION. Scientific, technical, or historical information from NASA programs, projects, and mission, often concerned with subjects having substantial public interest.

- TECHNICAL TRANSLATION. English-language translations of foreign scientific and technical material pertinent to NASA's mission.

Specialized services that complement the STI Program Office's diverse offerings include creating custom thesauri, building customized databases, organizing and publishing research results ... even providing videos.

For more information about the NASA STI Program Office, see the following:

- Access the NASA STI Program Home Page at http://www.sti.nasa.gov/STI-homepage.html

- E-mail your question via the Internet to help@sti.nasa.gov

- Fax your question to the NASA Access Help Desk at (301) 621-0134

- Telephone the NASA Access Help Desk at (301) 621-0390

- Write to:

NASA Access Help Desk

NASA Center for AeroSpace Information 7121 Standard Drive Hanover, MD 21076-1320 
NASA/TM-2000-209891, Vol. 214

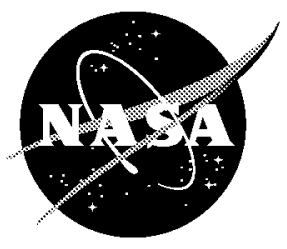

Technical Report Series on the Boreal Ecosystem-Atmosphere Study (BOREAS)

Forrest G. Hall and David E. Knapp, Editors

\section{Volume 214 \\ BOREAS TF-11 SSA-Fen 1995 \\ Leaf Area Index Data}

Timothy J. Arkebauer

University of Nebraska-Lincoln

National Aeronautics and

Space Administration

Goddard Space Flight Center

Greenbelt, Maryland 20771 


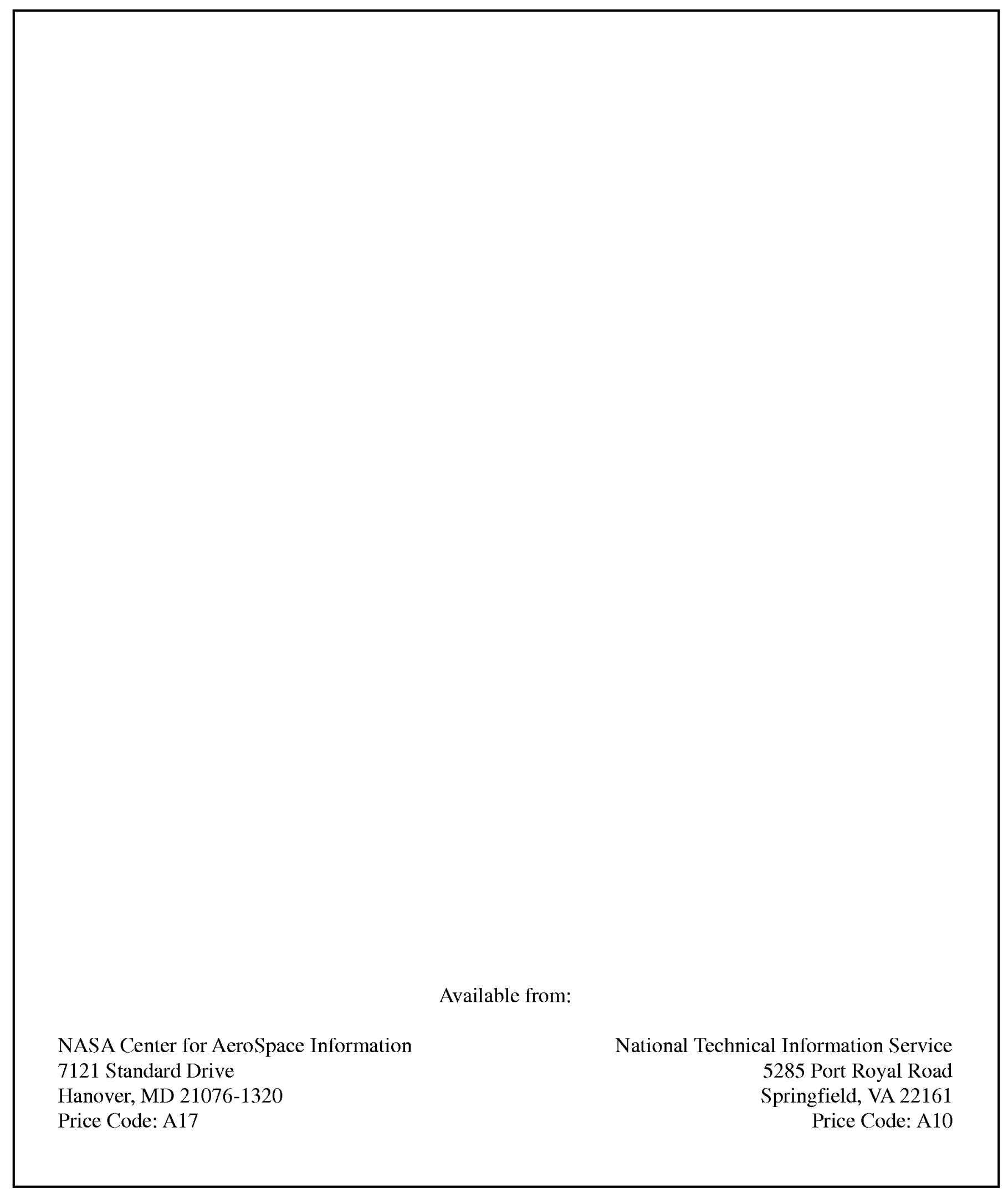




\section{BOREAS TF-11 SSA-Fen 1995 Leaf Area Index Data}

Timothy J. Arkebauer

\section{Summary}

The BOREAS TF-11 team gathered a variety of data to complement its tower flux measurements collected at the SSA-Fen site. These data are LAI measurements made by the TF-11 team throughout the 1995 growing season. The data include the LAI of plants that fall into six categories: total, Carex spp., Betula pumila, Menyanthes trifoliata, Salix spp., and other vascular plants. The data are stored in tabular ASCII files.

\section{Table of Contents}

1) Data Set Overview

2) Investigator(s)

3) Theory of Measurements

4) Equipment

5) Data Acquisition Methods

6) Observations

7) Data Description

8) Data Organization

9) Data Manipulations

10) Errors

11) Notes

12) Application of the Data Set

13) Future Modifications and Plans

14) Software

15) Data Access

16) Output Products and Availability

17) References

18) Glossary of Terms

19) List of Acronyms

20) Document Information

\section{Data Set Overview}

\subsection{Data Set Identification}

BOREAS TF-11 SSA-Fen 1995 Leaf Area Index Data

\subsection{Data Set Introduction}

These data are Leaf Area Index (LAI) measurements made by the Tower Flux (TF)-11 team at the BOReal Ecosystem-Atmosphere Study (BOREAS) Southern Study Area (SSA)-Fen site throughout the 1995 growing season. These data include the LAI of plants that fall into six categories: total, Carex spp., Betula pumila, Menyanthes trifoliata, Salix spp., and other vascular plants.

\subsection{Objective/Purpose}

The objective of this study was to quantify the distribution of green LAI during the growing season for the various plant species in the SSA-Fen. 


\subsection{Summary of Parameters}

Each data record includes the date and the LAI in each of six categories: total, Carex spp., Betula pumila, Menyanthes trifoliata, Salix spp., and other vascular plants.

\subsection{Discussion}

The overall project goal was to investigate the surface-atmosphere exchange of carbon dioxide and methane, and the associated energy fluxes at the SSA-Fen site. The LAI data were collected in support of the various components of the overall project.

\subsection{Related Data Sets}

BOREAS TF-11 SSA-Fen Tower Flux and Meteorological Data

BOREAS TF-11 SSA-Fen 1996 Water Surface Film Capping Data

BOREAS TF-11 SSA-Fen Leaf Gas Exchange Data

BOREAS TF-11 SSA-Fen Soil Surface CO2 Flux Data

\section{Investigator(s)}

\subsection{Investigator(s) Name and Title}

Dr. Timothy J. Arkebauer, Associate Professor

Department of Agronomy

University of Nebraska-Lincoln

Dr. Shashi B. Verma, Professor

Department of Agricultural Meteorology

University of Nebraska-Lincoln

\subsection{Title of Investigation}

Field Micrometeorological Measurements, Process-Level Studies and Modeling of Methane and Carbon Dioxide Fluxes in a Boreal Wetland Ecosystem (SSA-Fen)

\subsection{Contact Information}

\section{Contact 1:}

Dr. Timothy J. Arkebauer

Department of Agronomy

106 KCR Building

University of Nebraska

Lincoln, NE 68583-0817 USA

(402) 472-2847

(402) 472-3654 (fax)

tja@unlinfo.unl.edu

\section{Contact 2:}

David Knapp

Raytheon ITSS

NASA GSFC

Code 923

Greenbelt, MD 20771

(301) 286-1424

(301) 286-0239 (fax)

David.Knapp@gsfc.nasa.gov 


\section{Theory of Measurements}

LAI is the total leaf area per unit ground area. For broadleaf species, the leaf area is taken as one half the total surface area of the leaf, i.e., the area projected normal to the plane of the leaf.

\section{Equipment}

\subsection{Instrument Description}

A LI-COR LI-3100 leaf area meter was used to determine the leaf area of the samples.

\subsubsection{Collection Environment}

Samples were collected at the SSA-Fen site in ambient conditions from May to September 1995.

\subsubsection{Source/Platform}

None given.

\subsubsection{Source/Platform Mission Objectives}

None given.

\subsubsection{Key Variables}

Date, LAI for the following categories: total vascular plants, Carex spp., Betula pumila, Menyanthes trifoliata, Salix spp., and other vascular plants.

\subsubsection{Principles of Operation}

None given.

\subsubsection{Sensor/Instrument Measurement Geometry}

None given.

\subsubsection{Manufacturer of Instrument}

LI-COR, Inc.

P.O. Box 4425

4421 Superior Street

Lincoln, NE 68504 USA

(402) 467-3576

(402) 467-2819 (fax)

\subsection{Calibration}

None given.

\subsubsection{Specifications}

The LI-3100 was operated and maintained in accordance with the manufacturer's instructions.

\subsubsection{Tolerance}

None given.

\subsubsection{Frequency of Calibration}

None given.

\subsubsection{Other Calibration Information}

None. 


\section{Data Acquisition Methods}

A sampling area was chosen that had vegetation characteristics similar to the eddy correlation instrumentation "footprint." This area was located several hundred meters south of the main eddy correlation boardwalk.

A transect approximately $200 \mathrm{~m}$ long was laid out in an east-west direction. The transect was divided into four 50-m-long subtransects, giving a total of 20 samples. On each sampling date, five locations were chosen at random along each of the four subtransects giving a total of 20 samples. All the vegetation above the surface of a $0.25 \mathrm{~m}^{2}$ area at each location was harvested. Samples were placed in plastic ziplock bags and transported to the leaf area meter.

For each sample, green leaves were separated from stems and dead material. Leaf area of each of the following categories was determined: Carex spp., Betula pumila, Menyanthes trifoliata, Salix spp., and other vascular plants.

\section{Observations}

\subsection{Data Notes}

None.

\subsection{Field Notes}

A limited set of field notes and observations is available by request from T.J. Arkebauer (see Section 2.3).

\section{Data Description}

\subsection{Spatial Characteristics}

\subsubsection{Spatial Coverage}

All of the data were collected in the vicinity of the SSA-Fen flux tower site. This tower is located at the following North American Datum of 1983 (NAD83) coordinates:

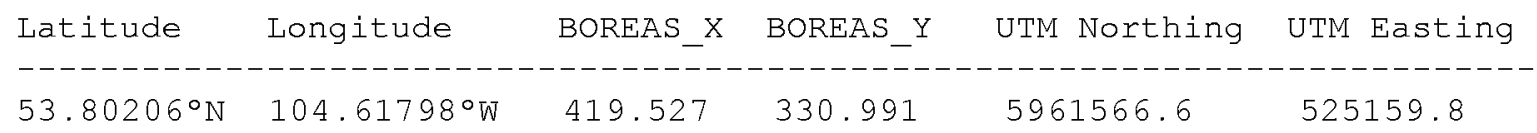

\subsubsection{Spatial Coverage Map}

None given.

\subsubsection{Spatial Resolution}

Each sample was from a $0.25 \mathrm{~m}^{2}$ area. There were 20 samples for each day on which measurements were taken. See Section 5 for details.

\subsubsection{Projection}

None given.

\subsubsection{Grid Description}

None given.

\subsection{Temporal Characteristics}




\subsubsection{Temporal Coverage}

Measurements were made on 20-May, 02-Jun, 22-Jun, 28-Jul, 17-Aug, 08-Sep, and 29-Sep-1995.

\subsubsection{Temporal Coverage Map}

None.

\subsubsection{Temporal Resolution}

These data were collected on particular days. See Section 7.2.1.

\subsection{Data Characteristics}

\subsubsection{Parameter/Variable}

The parameters contained in the data files on the CD-ROM are:

Column Name
SITE_NAME
SUB_SITE
DATE_OBS
MEAN_TOTAL_LAI
STD_ERR_TOTAL_LAI
SEDGE_LAI
BOGBIRCH_LAI
MENYANTHES_LAI
SALIX_LAI
OTHER_LAI
CRTFCN_CODE
REVISION_DATE

\subsubsection{Variable Description/Definition}

The descriptions of the parameters contained in the data files on the CD-ROM are:

\begin{tabular}{|c|c|}
\hline Column Name & Description \\
\hline SITE_NAME & $\begin{array}{l}\text { The identifier assigned to the site by BOREAS, } \\
\text { in the format sSS-TTT-CCCCC, where SSS identifies } \\
\text { the portion of the study area: NSA, SSA, REG, } \\
\text { TRN, and TTT identifies the cover type for the } \\
\text { site, } 999 \text { if unknown, and CCCCC is the identifier } \\
\text { for site, exactly what it means will vary with } \\
\text { site type. }\end{array}$ \\
\hline SUB_SITE & $\begin{array}{l}\text { The identifier assigned to the sub-site by } \\
\text { BOREAS, in the format GGGGG-IIIII, where GGGGG is } \\
\text { the group associated with the sub-site } \\
\text { instrument, e.g. HYD06 or STAFF, and IIIII is the } \\
\text { identifier for sub-site, often this will refer to } \\
\text { an instrument. }\end{array}$ \\
\hline DATE_OBS & The date on which the data were collected. \\
\hline MEAN_TOTAL_LAI & $\begin{array}{l}\text { The total vascular plant mean green Leaf Area } \\
\text { Index (mean of } 20 \text { samples). }\end{array}$ \\
\hline STD_ERR_TOTAL_LAI & $\begin{array}{l}\text { The standard error of the total vascular plant } \\
\text { mean green Leaf Area Index. }\end{array}$ \\
\hline SEDGH & The Leaf Area Index for all Carex sp \\
\hline
\end{tabular}


BOGBIRCH_LAI

MENYANTHES_LAI

SALIX_LAI

OTHER_LAI

CRTFCN_CODE

REVISION_DATE
The Leaf Area Index of Betula Pumila.

The Leaf Area Index for Menyanthes trifoliata.

The Leaf Area Index for Salix species.

The Leaf Area Index for all other vascular plant species.

The BOREAS certification level of the data.

Examples are CPI (Checked by PI), CGR (Certified by Group), PRE (Preliminary), and CPI-??? (CPI but questionable).

The most recent date when the information in the referenced data base table record was revised.

\subsubsection{Unit of Measurement}

The measurement units for the parameters contained in the data files on the CD-ROM are:

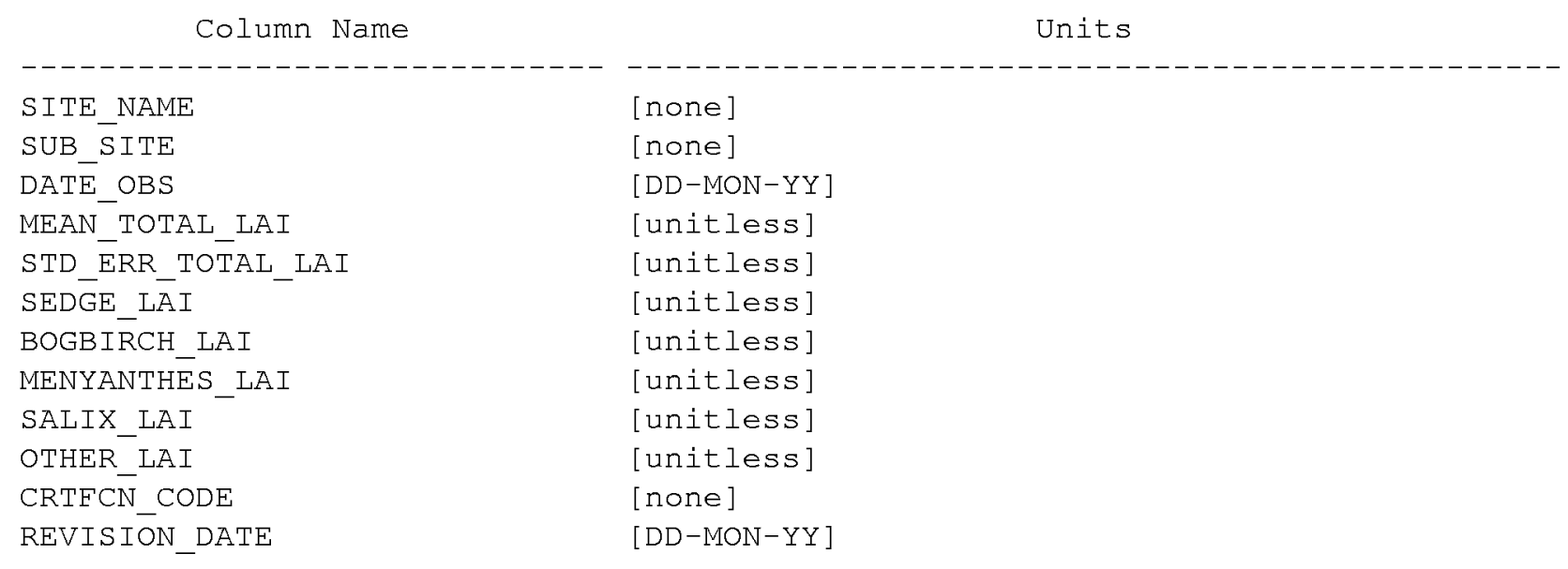

7.3.4 Data Source

The sources of the parameter values contained in the data files on the CD-ROM are:

\begin{tabular}{|c|c|}
\hline Column Name & Data Source \\
\hline SITE NAME & [Assigned by BORIS.] \\
\hline SUB_S SITE & [Assigned by BORIS.] \\
\hline DATE_OBS & [Supplied by Investigator.] \\
\hline MEAN_TOTAL_LAI & [Supplied by Investigator.] \\
\hline STD_ERR_TOTAL_LAI & [Supplied by Investigator.] \\
\hline SEDGE_LA I & [Supplied by Investigator.] \\
\hline BOGBIR $\bar{R} C H \_L A I$ & [Supplied by Investigator.] \\
\hline MENYANTHESS_LAI & [Supplied by Investigator.] \\
\hline SALIX_LAI & [Supplied by Investigator.] \\
\hline OTHER_LAI & [Supplied by Investigator.] \\
\hline CRTFCN_CODE & [Assigned by BORIS.] \\
\hline REVISION_DATE & [Assigned by BORIS.] \\
\hline
\end{tabular}




\subsubsection{Data Range}

The following table gives information about the parameter values found in the data files on the CD-ROM.

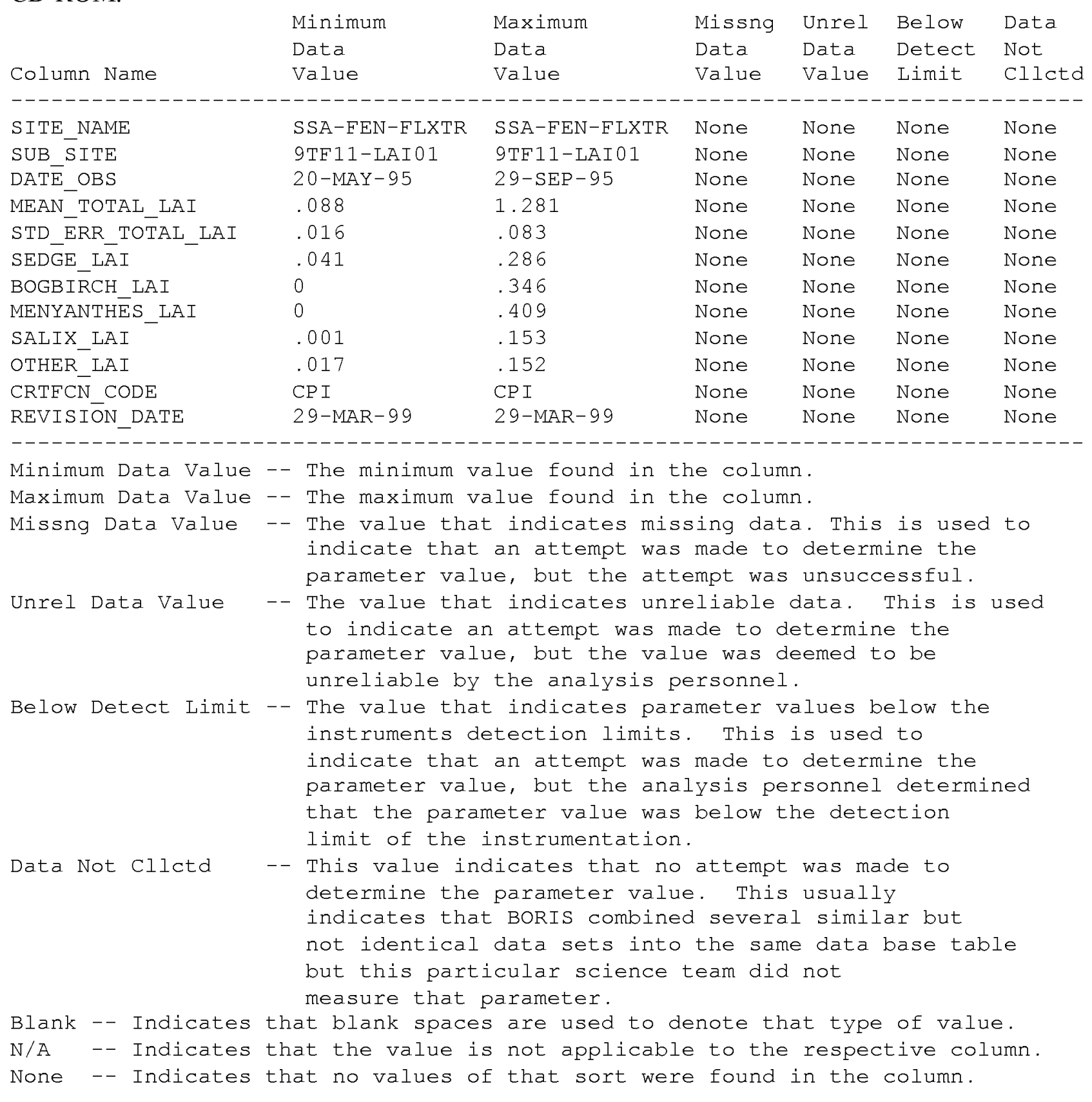

\subsection{Sample Data Record}

The following are wrapped versions of data records from a sample data file on the CD-ROM.

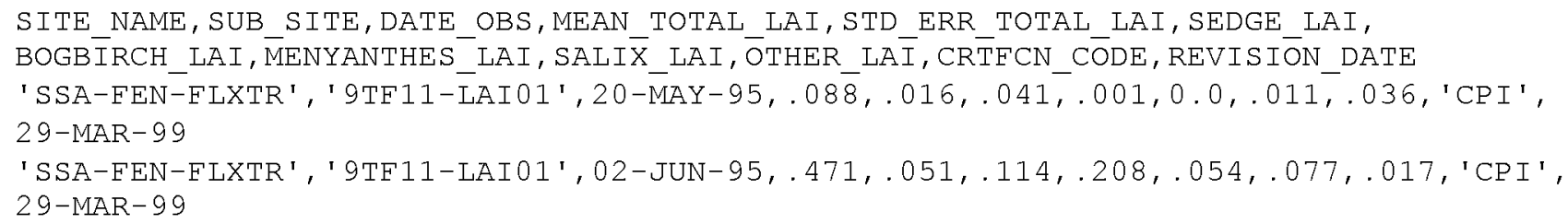




\section{Data Organization}

\subsection{Data Granularity}

The smallest amount of data that can be ordered from this data set is the entire set of data.

\subsection{Data Format}

The Compact Disk-Read-Only Memory (CD-ROM) files contain American Standard Code for Information Interchange (ASCII) numerical and character fields of varying length separated by commas. The character fields are enclosed with single apostrophe marks. There are no spaces between the fields.

Each data file on the CD-ROM has four header lines of Hyper-Text Markup Language (HTML) code at the top. When viewed with a Web browser, this code displays header information (data set title, location, date, acknowledgments, etc.) and a series of HTML links to associated data files and related data sets. Line 5 of each data file is a list of the column names, and line 6 and following lines contain the actual data.

\section{Data Manipulations}

\subsection{Formulae}

None given.

\subsubsection{Derivation Techniques and Algorithms}

None.

\subsection{Data Processing Sequence}

None given.

\subsubsection{Processing Steps}

- The BOREAS Information System (BORIS) received data from TF-11.

- $\quad$ BORIS standardized the units and loaded data into the data base.

- $\quad$ BORIS extracted data from data base into ASCII files.

\subsubsection{Processing Changes}

None.

\subsection{Calculations}

None.

\subsubsection{Special Corrections/Adjustments}

None.

\subsubsection{Calculated Variables}

None.

\subsection{Graphs and Plots}

None. 


\section{Errors}

\subsection{Sources of Error}

None given.

\subsection{Quality Assessment}

None given.

\subsubsection{Data Validation by Source} None given.

\subsubsection{Confidence Level/Accuracy Judgment}

None given.

\subsubsection{Measurement Error for Parameters}

None given.

\subsubsection{Additional Quality Assessment}

None given.

\subsubsection{Data Validation by Data Center}

BORIS staff loaded the data into the data base and checked for any inconsistencies during loading.

\section{Notes}

\subsection{Limitations of the Data}

None given.

\subsection{Known Problems with the Data}

No problems are known to exist. However, it should noted that there are significant numbers of nonvascular plants (e.g., green and brown mosses, lichens) present in the fen that were not measured.

\subsection{Usage Guidance}

The normal caveat of 'use at your own risk' applies. Correspondence with T.J. Arkebauer is encouraged when questions arise or if additional data set details are required.

\subsection{Other Relevant Information}

Dr. Evan C. Jolitz was responsible for most of the day-to-day coordination of the field measurements, and Ms. Marlene McCloud aided in the LAI measurements. Their assistance is greatly appreciated.

In 1994 an indirect technique (LI-COR LAI-2000 Plant Canopy Analyzer) was used to estimate the total LAI at the fen site. However, for a number of reasons, these values are regarded as unreliable. Those interested in the details are urged to correspond with T.J. Arkebauer (see Section 2.3).

\section{Application of the Data Set}

These data can be used as estimates of LAI at a typical fen in the boreal forest.

\section{Future Modifications and Plans}

None. 


\section{Software}

\subsection{Software Description}

None given.

\subsection{Software Access}

None given.

\section{Data Access}

The SSA-Fen 1995 LAI data are available from the Earth Observing System Data and Information System (EOSDIS) Oak Ridge National Laboratory (ORNL) Distributed Active Archive Center (DAAC).

\subsection{Contact Information}

For BOREAS data and documentation please contact:

ORNL DAAC User Services

Oak Ridge National Laboratory

P.O. Box 2008 MS-6407

Oak Ridge, TN 37831-6407

Phone: (423) 241-3952

Fax: (423) 574-4665

E-mail: ornldaac@ornl.gov or ornl@eos.nasa.gov

\subsection{Data Center Identification}

Earth Observing System Data and Information System (EOSDIS) Oak Ridge National Laboratory (ORNL) Distributed Active Archive Center (DAAC) for Biogeochemical Dynamics http://www-eosdis.ornl.gov/.

\subsection{Procedures for Obtaining Data}

Users may obtain data directly through the ORNL DAAC online search and order system [http://www-eosdis.ornl.gov/] and the anonymous FTP site [ftp://www-eosdis.ornl.gov/data/] or by contacting User Services by electronic mail, telephone, fax, letter, or personal visit using the contact information in Section 15.1.

\subsection{Data Center Status/Plans}

The ORNL DAAC is the primary source for BOREAS field measurement, image, GIS, and hardcopy data products. The BOREAS CD-ROM and data referenced or listed in inventories on the CD-ROM are available from the ORNL DAAC.

\section{Output Products and Availability}

\subsection{Tape Products}

None.

\subsection{Film Products}

None.

\subsection{Other Products}

These data are available on the BOREAS CD-ROM series. 


\section{References}

\subsection{Platform/Sensor/Instrument/Data Processing Documentation} None.

\subsection{Journal Articles and Study Reports}

Newcomer, J., D. Landis, S. Conrad, S. Curd, K. Huemmrich, D. Knapp, A. Morrell, J. Nickeson, A. Papagno, D. Rinker, R. Strub, T. Twine, F. Hall, and P. Sellers, eds. 2000. Collected Data of The Boreal Ecosystem-Atmosphere Study. NASA. CD-ROM.

Sellers, P. and F. Hall. 1994. Boreal Ecosystem-Atmosphere Study: Experiment Plan. Version 1994-3.0, NASA BOREAS Report (EXPLAN 94).

Sellers, P. and F. Hall. 1996. Boreal Ecosystem-Atmosphere Study: Experiment Plan. Version 1996-2.0, NASA BOREAS Report (EXPLAN 96).

Sellers, P., F. Hall, and K.F. Huemmrich. 1996. Boreal Ecosystem-Atmosphere Study: 1994 Operations. NASA BOREAS Report (OPS DOC 94).

Sellers, P., F. Hall, and K.F. Huemmrich. 1997. Boreal Ecosystem-Atmosphere Study: 1996 Operations. NASA BOREAS Report (OPS DOC 96).

Sellers, P., F. Hall, H. Margolis, B. Kelly, D. Baldocchi, G. den Hartog, J. Cihlar, M.G. Ryan, B. Goodison, P. Crill, K.J. Ranson, D. Lettenmaier, and D.E. Wickland. 1995. The boreal ecosystem-atmosphere study (BOREAS): an overview and early results from the 1994 field year. Bulletin of the American Meteorological Society. 76(9):1549-1577.

Sellers, P.J., F.G. Hall, R.D. Kelly, A. Black, D. Baldocchi, J. Berry, M. Ryan, K.J. Ranson, P.M. Crill, D.P. Lettenmaier, H. Margolis, J. Cihlar, J. Newcomer, D. Fitzjarrald, P.G. Jarvis, S.T. Gower, D. Halliwell, D. Williams, B. Goodison, D.E. Wickland, and F.E. Guertin. 1997. BOREAS in 1997: Experiment Overview, Scientific Results and Future Directions. Journal of Geophysical Research 102(D24): 28,731-28,770.

Suyker, A.E., S.B. Verma, and T.J. Arkebauer. 1997. Season-long measurement of carbon dioxide exchange in a boreal fen. Journal of Geophysical Research 102 (D24): 29,021-29,028.

\subsection{Archive/DBMS Usage Documentation}

None.

\section{Glossary of Terms}

None.

\section{List of Acronyms}

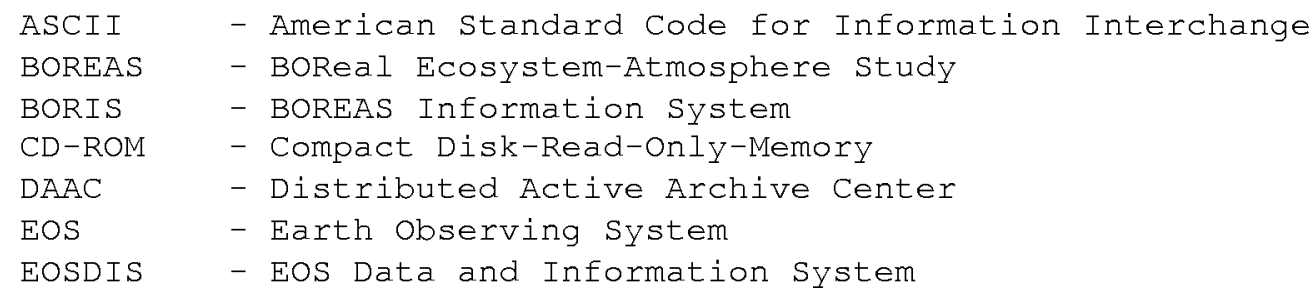




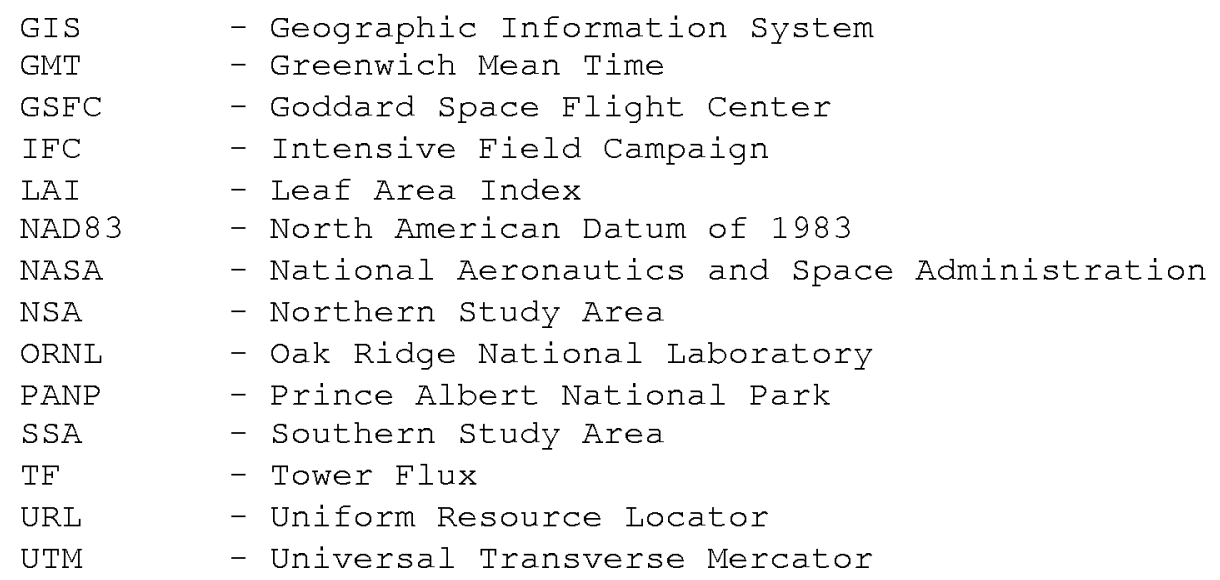

\section{Document Information}

\subsection{Document Revision Date of This Document}

Written: 30-Jun-1997

Last Revised: 12-Sep-1999

\subsection{Document Review Date(s)}

BORIS Review: 19-Apr-1999

Science Review:

\subsection{Document ID}

\subsection{Citation}

When using these data, please acknowledge T.J. Arkebauer and E.C. Jolitz and include citations of relevant papers in Section 17.2.

If using data from the BOREAS CD-ROM series, also reference the data as:

Arkebauer, T.J. and S.B. Verma, "Field Micrometeorological Measurements, Process-Level Studies and Modeling of Methane and Carbon Dioxide Fluxes in a Boreal Wetland Ecosystem (SSA-Fen)." In Collected Data of The Boreal Ecosystem-Atmosphere Study. Eds. J. Newcomer, D. Landis, S. Conrad, S. Curd, K. Huemmrich, D. Knapp, A. Morrell, J. Nickeson, A. Papagno, D. Rinker, R. Strub, T. Twine, F. Hall, and P. Sellers. CD-ROM. NASA, 2000.

Also, cite the BOREAS CD-ROM set as:

Newcomer, J., D. Landis, S. Conrad, S. Curd, K. Huemmrich, D. Knapp, A. Morrell, J. Nickeson, A. Papagno, D. Rinker, R. Strub, T. Twine, F. Hall, and P. Sellers, eds. Collected Data of The Boreal Ecosystem-Atmosphere Study. NASA. CD-ROM. NASA, 2000.

\subsection{Document Curator}

\subsection{Document URL}


Public reporting burden for this collection of information is estimated to average 1 hour per response, including the time for reviewing instructions, searching existing data sources, gathering and maintaining the data needed, and completing and reviewing the collection of information. Send comments regarding this burden estimate or any other aspect of this collection of information including suggestions for reducing this burden, to Washington Headquarters Services, Directorate for Information Operations and Reports, 1215 Jefferson Davis Highway, Suite 1204, Arlington, VA 22202-4302, and to the Office of Management and Budget, Paperwork Reduction Project (0704-0188), Washington, DC 20503.

\begin{tabular}{|l|l|c}
\hline 1. AGENCY USE ONLY (Leave blank) & 2. REPORT DATE \\
November 2000 & $\begin{array}{c}\text { 3. REPORT TYPE AND DATES COVERED } \\
\text { Technical Memorandum }\end{array}$
\end{tabular}

4. TITLE AND SUBTITLE

Technical Report Series on the Boreal Ecosystem-Atmosphere Study (BOREAS) BOREAS TF-11 SSA-Fen 1995 Leaf Area Index Data

\section{AUTHOR(S)}

Timothy J. Arkebauer

Forrest G. Hall and David E. Knapp, Editors

7. PERFORMING ORGANIZATION NAME(S) AND ADDRESS (ES)

Goddard Space Flight Center

Greenbelt, Maryland 20771

9. SPONSORING / MONITORING AGENCY NAME(S) AND ADDRESS (ES)

National Aeronautics and Space Administration

Washington, DC 20546-0001
5. FUNDING NUMBERS

923

RTOP: 923-462-33-01

\section{SUPPLEMENTARY NOTES}

T.J. Arkebauer: University of Nebraska-Lincoln;

D.E. Knapp: Raytheon ITSS, NASA Goddard Space Flight Center, Greenbelt, Maryland

\begin{tabular}{l|l}
\hline 12a. DISTRIBUTION / AVAILABILITY STATEMENT & 12b. DISTRIBUTION CODE \\
Unclassified-Unlimited & \\
Subject Category: 43 & \\
Report available from the NASA Center for AeroSpace Information, \\
7121 Standard Drive, Hanover, MD 21076-1320. (301) 621-0390.
\end{tabular}

13. ABSTRACT (Maximum 200 words)

The BOREAS TF-11 team gathered a variety of data to complement its tower flux measurements collected at the SSA-Fen site. These data are LAI measurements made by the TF-11 team throughout the 1995 growing season. The data include the LAI of plants that fall into six categories: total, Carex spp., Betula pumila, Menyanthes trifoliata, Salix spp., and other vascular plants. The data are stored in tabular ASCII files.

\section{SUBJECT TERMS \\ BOREAS, tower flux, leaf area index data.

\begin{tabular}{|l|l|} 
& \\
\hline $\begin{array}{l}\text { 17. SECURITY CLASSIFICATION } \\
\text { OF REPORT } \\
\text { Unclassified }\end{array}$ & $\begin{array}{c}\text { SECURITY CLASSIFICATION } \\
\text { OF THIS PAGE }\end{array}$ \\
& Unclassified \\
\hline
\end{tabular}

8. PEFORMING ORGANIZATION

2000-03136-0

\section{AGENCY REPORT NUMBER}

TM-2000-209891

Vol. 214
19. SECURITY CLASSIFICATION OF ABSTRACT

Unclassified
15. NUMBER OF PAGES

12

16. PRICE CODE
20. LIMITATION OF ABSTRACT

UL 
